\title{
Bacterial metabolism of 3-chloroacrylic acid
}

\author{
S. Hartmans, ${ }^{*}$ M. W. Jansen, M. J. van Der Werf and J. A. M. De Bont \\ Division of Industrial Microbiology, Agricultural University, PO Box 8129, 6700 EV Wageningen, The Netherlands
}

(Received 16 March 1991; accepted 8 May 1991)

\begin{abstract}
Two bacterial strains were isolated with 3-chloroacrylic acid (CAA) as sole source of carbon and energy. Strain CAA1, a Pseudomonas cepacia sp., was capable of growth with only the cis-isomer of CAA. Strain CAA2, a coryneform bacterium, utilized both isomers of CAA as sole source of carbon and energy. Strain CAA1 contained cis-CAA hydratase and strain CAA2 contained two hydratases, one with cis-CAA hydratase activity and one with trans-CAA hydratase activity. The product of the hydratase activities with CAA was malonate semialdehyde. In both strains malonate semialdehyde was subsequently decarboxylated by a cofactor-independent decarboxylase yielding acetaldehyde and $\mathrm{CO}_{2}$.
\end{abstract}

\section{Introduction}

The biodegradability of halogenated hydrocarbons receives considerable attention in view of the persistence of some of these compounds in the environment. Degradation of a number of chlorinated hydrocarbons by pure cultures has, however, been demonstrated. In several cases the dechlorination step has also been characterized. Specific dechlorination reactions of chlorinated hydrocarbons that have been studied in detail are the hydrolytic dehalogenases acting on chlorinated alkanes (Kohler-Staub \& Leisinger, 1985; Keuning et al., 1985; Scholtz et al., 1987) or 2-chloroalkanoic acids (Motosugi et al., 1982; Smith et al., 1990). The oxidative dechlorination of chlorinated alkanes has also been reported (Yokota et al., 1986). The dechlorination reactions of unsaturated chlorinated hydrocarbons have been less well studied. Within this category of compounds most attention has focussed on the chlorinated ethenes due to their broad use and widespread occurrence in the environment. Transformation of all chlorinated ethenes has been observed under anaerobic conditions (Freedman \& Gossett, 1989; Bagley \& Gossett, 1990; Fathepure \& Boyd, 1988). Aerobic transformation has been observed only for mono-, diand trichloroethenes. Transformation (co-oxidation) of these compounds has been demonstrated with various types of micro-organisms (e.g. toluene-, methane-, alkane- and ammonium-utilizers) (Wackett et al., 1989).

Abbreviations: CAA, 3-chloroacrylic acid; DAP, diaminopimelic acid.
Micro-organisms utilizing chlorinated ethenes as sole carbon and energy source have been isolated only with monochloroethene (vinyl chloride) (Hartmans et al., 1985). The initial step in the aerobic transformation of chlorinated ethenes is generally assumed to be an epoxidation of the carbon-carbon double bond (Hartmans et al., 1989). The further metabolism of the reactive and unstable chloroepoxides is not known, but extensive dechlorination is often observed.

Aerobic degradation of 3-chloroallyl alcohol, which also contains a chloroethenyl group, has been studied by Belser \& Castro (1971). It is formed from the soil disinfectant 1,3-dichloropropene as a result of chemical hydrolysis. The 3-chloroallyl-alcohol-degrading Pseudomonas sp. isolated by Belser \& Castro (1971) degrades 3-chloroallyl alcohol via 3-chloroacrylic acid. Incubation of whole cells with 3-chloroacrylic acid resulted in the formation of 3-oxopropanoic acid (malonate semialdehyde). The dechlorination of 3-chloroacrylic acid was, however, not investigated in any further detail.

We now report on the dechlorination of 3-chloroacrylic acid in more detail. The 3-chloroacrylic acid degradative pathway and the dechlorination reaction in particular were studied in two bacterial strains isolated with 3-chloroacrylic acid (Hartmans et al., 1988).

\section{Methods}

Chemicals. cis- and trans-3-chloroacrylic acid (CAA) were from Ventron (Karlsruhe, FRG); 3-chloropropionic acid, cis- and trans1,2-dichloroethene, 1,3-dichloropropene, fumaric acid, acrylic acid, crotonic acid, cinnamic acid, methacrylic acid and MOPS were from 
Janssen (Beerse, Belgium). trans-2-Pentenoic acid and maleic acid were from Aldrich, 1-chloropropene was obtained from ICN Biomedicals (New York, USA) and vinyl chloride was from Hoek Loos (Schiedam, The Netherlands). 2-Chloroacrylic acid was from Heraeus (Karlsruhe, FRG). 3-Chloroallyl alcohol was a gift from the Institute for Pesticide Research (Wageningen, The Netherlands). L- and meso-diaminopimelic acid (DAP) were from L. Light \& Co. (Colnbrook, UK), DL-isocitrate and Coenzyme $\mathrm{A}$ were from Sigma and $\mathrm{NAD}^{+}$and $\mathrm{NADP}^{+}$were from Boehringer. Other chemicals were from Merck.

Isolation and cultivation. Enrichment cultures were set up using a mixture of soil and water samples as inoculum in mineral salts medium with one of the following compounds as sole carbon source. 1,3-Dichloropropene and chloroallyl alcohol were added at a concentration of $1 \mathrm{~mm}$ in Erlenmeyer flasks sealed with Mininert valves to prevent evaporation. cis- or trans-CAA were added at a concentration of $2.5 \mathrm{~mm}$. After incubation for 2 weeks at $30^{\circ} \mathrm{C} 1 \mathrm{ml}$ from the enrichment cultures was transferred to fresh medium with the same carbon source. After growth was observed in these cultures, cells were streaked to purity on glucose/yeast extract agar plates. Non-sterile controls without inoculum were also made and incubated under identical conditions to monitor any chemical hydrolysis of the chlorinated substrates. 1,3-Dichloropropene was assayed by taking headspace samples which were analysed on a gas chromatograph. Chemical hydrolysis or biodegradation of the two other compounds was monitored by determining the rates of formation of $\mathrm{Cl}^{-}$in both the enrichment cultures and the non-sterile controls. From the depletion curve observed for 1,3-dichloropropene in the control flasks a half-life of $92 \mathrm{~h}$ was calculated.

The mineral salts medium contained, per litre of deionized water: $3.88 \mathrm{~g} \mathrm{~K}_{2} \mathrm{HPO}_{4}, 2.13 \mathrm{~g} \mathrm{NaH} \mathrm{PO}_{4} .2 \mathrm{H}_{2} \mathrm{O}, 2.0 \mathrm{~g}\left(\mathrm{NH}_{4}\right)_{2} \mathrm{SO}_{4}, 0.1 \mathrm{~g}$ $\mathrm{MgCl}_{2} .6 \mathrm{H}_{2} \mathrm{O}, 10 \mathrm{mg}$ EDTA, $2 \mathrm{mg} \mathrm{ZnSO}{ }_{4} .7 \mathrm{H}_{2} \mathrm{O}, 1 \mathrm{mg} \mathrm{CaCl}{ }_{2} .2 \mathrm{H}_{2} \mathrm{O}$, $5 \mathrm{mg} \mathrm{FeSO} \cdot .7 \mathrm{H}_{2} \mathrm{O}, 0.2 \mathrm{mg} \mathrm{Na} \mathrm{MoO}_{4} .2 \mathrm{H}_{2} \mathrm{O}, 0.2 \mathrm{mg} \mathrm{CuSO}{ }_{4} .5 \mathrm{H}_{2} \mathrm{O}$, $0.4 \mathrm{mg} \mathrm{CoCl}{ }_{2} .6 \mathrm{H}_{2} \mathrm{O}$ and $1 \mathrm{mg} \mathrm{MnCl}_{2} \cdot 2 \mathrm{H}_{2} \mathrm{O}$.

Cultures were grown in the mineral salts medium with $0.1 \%(w / v)$ carbon source, unless indicated otherwise. When CAA was used as a carbon source it was sterilized separately by filtration and added at a concentration of $5 \mathrm{~mm}$. Culture conditions, maintenance of strains, culture harvesting and storage of harvested cells were as previously described (Hartmans \& de Bont, 1986).

Preparation of cell extracts. Crude cell extracts and dialysed extracts were prepared as described previously (Hartmans \& de Bont, 1986).

Separation of hydratases. Cell extract (150 mg protein) from glucosegrown $(0.25 \%, \mathrm{w} / \mathrm{v})$ strain CAA2 cells, which had been induced with 2 mM-cis-CAA in the late-exponential growth phase, was fractionated on a DEAE-Sepharose CL-6B column $(25 \times 2.5 \mathrm{~cm})$. Elution was with $50 \mathrm{~mm}$-potassium phosphate buffer, $\mathrm{pH} 7.0$, with a linear gradient of $100-500 \mathrm{~mm}-\mathrm{NaCl}$ at a flow rate of $50 \mathrm{ml} \mathrm{h}^{-1}$. Fractions of vol. $8.3 \mathrm{ml}$ were collected.

Fractions containing hydratase activity were concentrated and washed with phosphate buffer $(50 \mathrm{mM}, \mathrm{pH} \mathrm{7.0)}$, in order to reduce the $\mathrm{Cl}^{-}$concentration, by ultrafiltration across an Amicon YM 10 membrane in an Amicon 8050 concentrator. These hydratase preparations could be stored at $-20^{\circ} \mathrm{C}$ without any apparent loss of activity and were used for $K_{\mathrm{m}}, \mathrm{pH}$ optimum and substrate specificity determinations.

Isolation of 2,4-dinitrophenylhydrazones. The partially purified hydratase preparations were incubated with the appropriate CAA isomer until reaction was complete. After filtration over an Amicon YM 10 filter (to remove protein) the filtrate was reacted with 2,4-dinitrophenylhydrazine and analysed by mass spectrometry as described by van den Tweel \& de Bont (1985).
Enzyme assays. All assays were done at $30^{\circ} \mathrm{C}$. Spectrophotometric assays were done on a Perkin-Elmer $550 \mathrm{~A}$ spectrophotometer. Activities are expressed as nmol product formed $\min ^{-1}$ (mg protein $)^{-1}$. One unit (U) is the amount of enzyme which catalyses the transformation of $1 \mu \mathrm{mol}$ substrate $\mathrm{min}^{-1}$.

(i) 3-Chloroacrylic acid hydratase. The reaction mixture (total vol. $2 \mathrm{ml}$ ) contained $100 \mu \mathrm{mol}$ potassium phosphate, $\mathrm{pH} 7 \cdot 0,10 \mu \mathrm{mol}$ phenylhydrazine hydrochloride and cell extract. The reaction was initiated by the addition of $10 \mu \mathrm{mol}$ cis- or trans-CAA and phenylhydrazone formation was recorded at $315 \mathrm{~nm}$. By comparing phenylhydrazone formation rates with $\mathrm{Cl}^{-}$liberation rates (amperometrically) under the same conditions, a molar absorption coefficient for the phenylhydrazone of $2.2 \times 10^{3} \mathrm{Imol}^{-1} \mathrm{~cm}^{-1}$ was calculated for both isomers of CAA. At $300 \mathrm{~nm}$ an absorption coefficient of $4.7 \times 10^{3} 1 \mathrm{~mol}^{-1} \mathrm{~cm}^{-1}$ was calculated. Van den Tweel \& de Bont (1985) reported an absorption coefficient for the phenylhydrazone of malonate semialdehyde of $4 \times 10^{3} 1 \mathrm{~mol}^{-1} \mathrm{~cm}^{-1}$ at $300 \mathrm{~nm}$.

(ii) Fumarase (EC 4.2.1.2). Activity was assayed at $240 \mathrm{~nm}$ (fumarate formation) in a reaction mixture (total vol. $2 \mathrm{ml}$ ) containing $100 \mu \mathrm{mol}$ potassium phosphate and $5 \mu \mathrm{mol} \mathrm{L}$-malate and enzyme. An absorption coefficient of $2.3 \times 10^{3} \mathrm{1} \mathrm{mol}^{-1} \mathrm{~cm}^{-1}$ was used in calculating fumarase activities.

(iii) Malonate semialdehyde decarboxylase (EC 4.1.1.-). Activity was determined by assaying $\mathrm{CO}_{2}$ or acetaldehyde formation in $30 \mathrm{ml}$ serum bottles containing $50 \mu \mathrm{mol}$ potassium phosphate, $\mathrm{pH} 7 \cdot 0,5 \mu \mathrm{mol}$ cis-CAA, $0.2 \mathrm{U}$ partially purified cis-CAA hydratase devoid of malonate semialdehyde decarboxylase activity and cell extract in a total volume of $1 \mathrm{ml}$.

(iv) Malonate decarboxylase (EC 4.1.1.-). Activity was determined by assaying $\mathrm{CO}_{2}$ formation in $30 \mathrm{ml}$ serum bottles containing $50 \mu \mathrm{mol}$ potassium phosphate, $\mathrm{pH} 7 \cdot 0,5 \mu \mathrm{mol}$ malonate and cell extract in a total volume of $1 \mathrm{ml}$.

(v) Acetaldehyde dehydrogenase (EC 1.2.1.3). The reaction mixture (total vol. $2 \mathrm{ml}$ ) contained $100 \mu \mathrm{mol}$ Tris $/ \mathrm{HCl}, \mathrm{pH} 8 \cdot 0,2 \mu \mathrm{mol} \mathrm{NAD}{ }^{+}$ and cell extract. The reaction was started by the addition of $10 \mu \mathrm{mol}$ acetaldehyde and NADH formation was recorded at $340 \mathrm{~nm}$.

(vi) Isocitrate lyase (EC 4.1.3.1). The reaction mixture (total vol. $2 \mathrm{ml}$ ) contained cell extract, $100 \mu \mathrm{mol}$ Tris $/ \mathrm{HCl}, \mathrm{pH} 8 \cdot 0,100 \mu \mathrm{mol}$ $\mathrm{MgCl}_{2}$ and $10 \mu \mathrm{mol}$ phenylhydrazine hydrochloride. The reaction was started by the addition of $20 \mu \mathrm{mol}$ isocitrate and hydrazone formation was recorded at $324 \mathrm{~nm}$. Activities were calculated using an absorption coefficient for the phenylhydrazone of $1.7 \times 10^{4} 1 \mathrm{~mol}^{-1} \mathrm{~cm}^{-1}$.

(vii) Isocitrate dehydrogenase (EC 1.1.1.42). The reaction mixture (total vol. $2 \mathrm{ml}$ ) contained cell extract, $100 \mu \mathrm{mol}$ Tris $/ \mathrm{HCl}, \mathrm{pH} 8.0$, $2 \mu \mathrm{mol} \mathrm{NADP}{ }^{+}$and $2 \mu \mathrm{mol} \mathrm{MgSO}_{4}$. The reaction was started by adding $8 \mu \mathrm{mol}$ isocitrate and NADPH formation was recorded at $340 \mathrm{~nm}$.

Analytical methods. Protein was determined by the Lowry method using bovine serum albumin as standard. $\mathrm{CO}_{2}$ concentrations were determined by analysing headspace samples on a gas chromatograph (Hartmans et al., 1985). Acetaldehyde and vinyl chloride (at $180^{\circ} \mathrm{C}$ ) and 1,3-dichloropropene (at $210^{\circ} \mathrm{C}$ ) were assayed on a Packard 430 gas chromatograph fitted with a Porapak R column (Hartmans et al., 1985). $\mathrm{Cl}^{-}$were determined colorimetrically (Bergmann \& Sanik, 1957) or amperometrically (Hartmans et al., 1985). The substrate specificity of the hydratases with the chlorinated substrates was determined by incubating enzyme and $5 \mathrm{mM}$-substrate in $100 \mathrm{mM}$-MOPS/KOH buffer and assaying $\mathrm{Cl}^{-}$formation by the colorimetric method. The substrate specificity of the hydratases with the nonchlorinated substrates was determined spectrophotometrically at $220 \mathrm{~nm}$ by incubating $0.5 \mathrm{~mm}$ substrate in $50 \mathrm{~mm}$-potassium phosphate buffer, $\mathrm{pH} 7$, with 0.05 Units of partially purified hydratase $\mathrm{ml}^{-1}$. Chromatography of whole-cell hydrolysates was done as described by Becker et al. (1964). Arthrobacter globiformis (ATCC 8010), Arthrobacter simplex (NCIB 8929) and 
Brevibacterium linens (ATCC 9175) were used as reference strains containing lysine, L-DAP and meso-DAP respectively. Phenylhydrazones were extracted with ethyl acetate, which was subsequently removed by evaporation, and assayed by reverse phase HPLC using a C-18 column $(200 \times 3 \mathrm{~mm}$; Chrompack $)$ and detected at $280 \mathrm{~nm}$ by means of a Perkin-Elmer variable wavelength detector. The eluent was acrylonitrile in Milli-Q water $(60: 40, \mathrm{v} / \mathrm{v})$ at a flow rate of $0.6 \mathrm{ml} \mathrm{min}^{-1}$.

\section{Results and Discussion}

\section{Isolation and characterization of new isolates}

To isolate micro-organisms containing CAA-dechlorinating activity, enrichment cultures were set up with 1,3-dichloropropene, chloroallyl alcohol or one of the CAA isomers as the sole carbon source. With 1,3dichloropropene and chloroallyl alcohol no differences were observed either in substrate depletion or $\mathrm{Cl}^{-}$ formation between enrichment cultures and the controls without inoculum. Although biodegradation of 1,3dichloropropene has been observed (van Dijk, 1980), to our knowledge, no pure cultures have been isolated. In contrast, enrichment cultures with either isomer of CAA as sole carbon source resulted in rapid microbial growth. Growth was also observed in the non-sterile control containing trans-CAA. Strains CAA1 and CAA2 were isolated from the enrichment cultures with cis-CAA and trans-CAA respectively.

Strain CAAl was a Gram-negative, straight and motile rod. It was catalase- and oxidase positive and possessed $\beta$-galactosidase activity. Denitrification, indole formation, urease activity and gelatin hydrolysis were negative. Glucose, arabinose, mannose, mannitol, $\mathrm{N}$-acetylglucoside, gluconic acid, capric acid, adipic acid, malic acid and phenylacetic acid were all utilized as growth substrates. Maltose was not utilized. Based on these observations strain CAA1 was identified as a strain of Pseudomonas cepacia. The organism also utilized acetate, propionate, fumarate and malonate as growth substrates. trans-CAA, acrylic acid and methanol were not utilized. The doubling time of strain CAAl with cis-CAA was $2.6 \mathrm{~h}$ and with malonate, a possible intermediate of cis-CAA metabolism, $2 \cdot 2 \mathrm{~h}$.

Strain CAA2 was creamy to light-orange in colour. The isolate was Gram-positive and not acid fast. Catalase and oxidase tests were positive. The morphology of strain CAA2 depended on the age of the culture. In exponentially growing cultures strain CAA2 occurred as irregular rods (Fig. $1 a$ ). In the stationary growth phase strain CAA2 formed coccoid cells, often in the V-arrangement typical of coryneform bacteria (Fig. $1 b$ ). Thin-layer chromatography of strain CAA2 hydrolysates showed meso-DAP to be present. Based on the presence of meso-DAP and the microscopic morphology, strain CAA2 was tentatively designated as a Brevibacterium sp. (Jones \& Keddie, 1986). The isolate grew with both CAA isomers, as well as with acetate, propionate and fumarate. Malonate, acrylic acid and methanol were not utilized as sole carbon source. The doubling time of strain CAA2 with cis-CAA was $3 \mathrm{~h}$. The doubling time with trans-CAA was difficult to determine as concentrations higher than 2-4 mM-trans-CAA clearly inhibited growth.

Neither strain grew with 1,3-dichloropropene or chloroallyl alcohol at a concentration of $1 \mathrm{mM}$.

\section{CAA dechlorinating activities}

The initial step in CAA metabolism was studied using

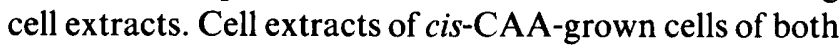
strains exhibited rapid $\mathrm{Cl}^{-}$formation upon addition of cis-CAA. Dialysis of crude extracts did not affect the specific rate at which $\mathrm{Cl}^{-}$was liberated from cis-CAA. Cell extracts of cis-CAA-grown strain CAAl did not dechlorinate trans-CAA, whereas cell extracts of strain CAA2 grown with cis-CAA dechlorinated both isomers of CAA. Extracts of trans-CAA-grown strain CAA2 also dechlorinated both isomers of CAA. The cofactorindependent $\mathrm{Cl}^{-}$formation observed in cell-free extracts after cis-CAA addition could be explained by assuming an enzymic hydration of the double bond of cis-CAA. Hydration of the double bond would yield 3-chloro2-hydroxypropanoic acid or the unstable 3-chloro3-hydroxypropanoic acid, which rapidly chemically decomposes to malonate semialdehyde (3-oxopropanoic acid) and $\mathrm{HCl}$. This would be in accordance with the previously reported formation of malonate semialdehyde by whole cells incubated with cis-CAA (Belser \& Castro, 1971). A similar type of reaction has been reported for the hydration by fumarase of monofluorofumarate yielding $\alpha$-fluorohydrin ( $\alpha$-fluoromalate) which subsequently decomposed to oxaloacetate. Hydration of monochlorofumarate with fumarase, however, yielded the chemically stable $\beta$-chloro-threo-L-malate (Marletta et al., 1982).

Larger amounts of cells were required to study the dechlorinating activities in more detail and to identify the product of the reaction. As CAA is relatively expensive, strain CAA2 was grown on glucose with 2 mM-cis-CAA added in the late-exponential growth phase ( $2 \mathrm{~h}$ before harvesting) to produce biomass with dechlorinating activities. Cells cultivated in this manner contained specific dechlorinating activities similar to the levels present in cells grown with cis-CAA as sole carbon and energy source. With extracts from cells cultivated in 

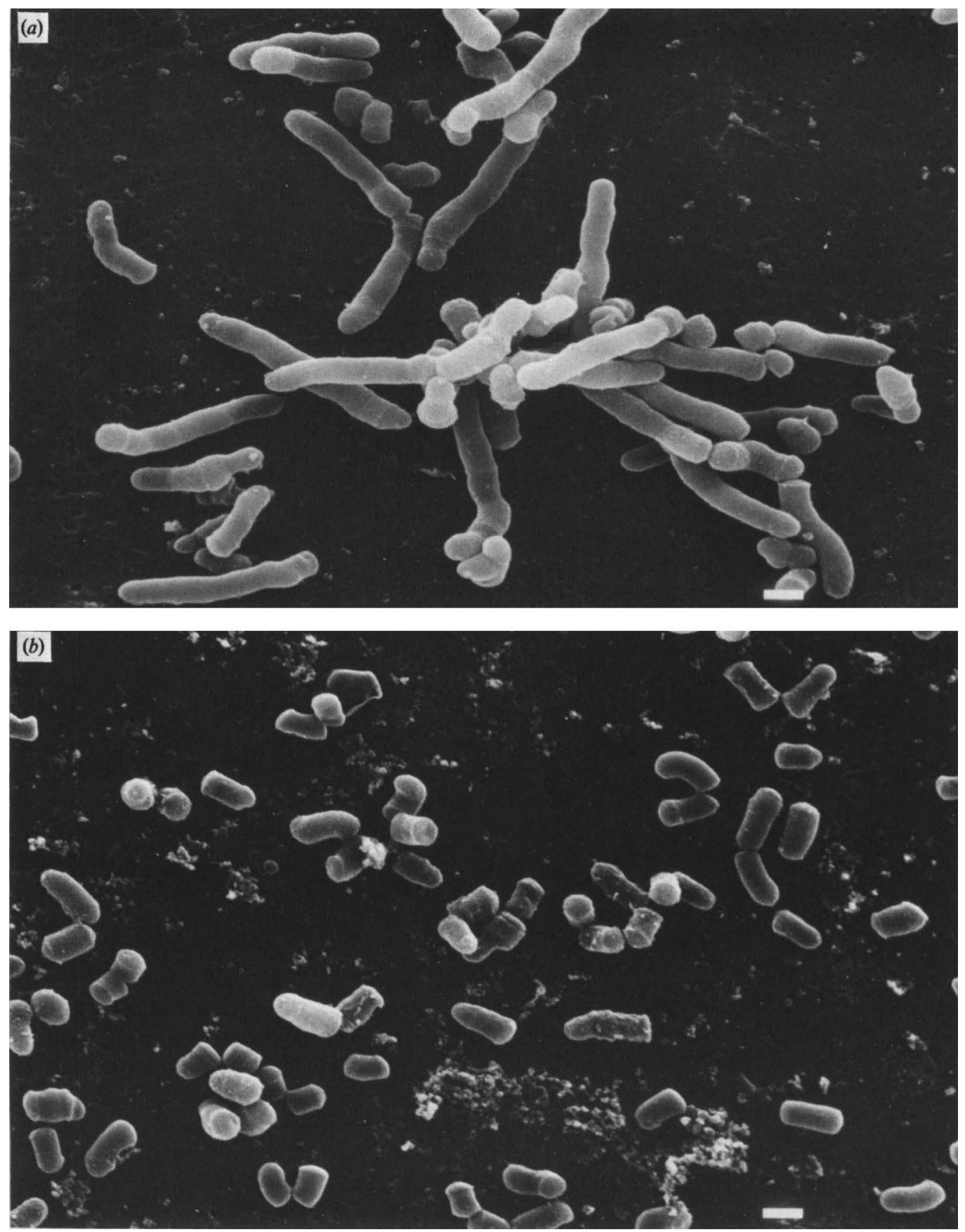

Fig. 1. Photomicrographs of strain CAA2 after growth for $8 \mathrm{~h}(a)$ and $96 \mathrm{~h}(b)$ on mineral salts medium with $0 \cdot 1 \%(w / v)$ glucose. Bars, $1 \mu \mathrm{m}$.

this manner the dechlorinating activities of strain CAA2 were investigated in more detail.

The activities were partially purified using anionexchange column chromatography. Fractionation of extracts on a DEAE-Sepharose CL-6B column resulted in separation of the cis- and trans-CAA dechlorinating activities (Fig. 2), indicating that the two isomers are dechlorinated by two distinct enzymes. Fumarase activity was also located. No fumarase activity coincided with either of the two CAA-dechlorinating activities. The fractions containing the respective dechlorinating activities were pooled and dialysed to remove excess $\mathrm{Cl}^{-}$. These partially purified preparations were used to identify the product of the dechlorinating reaction and to 


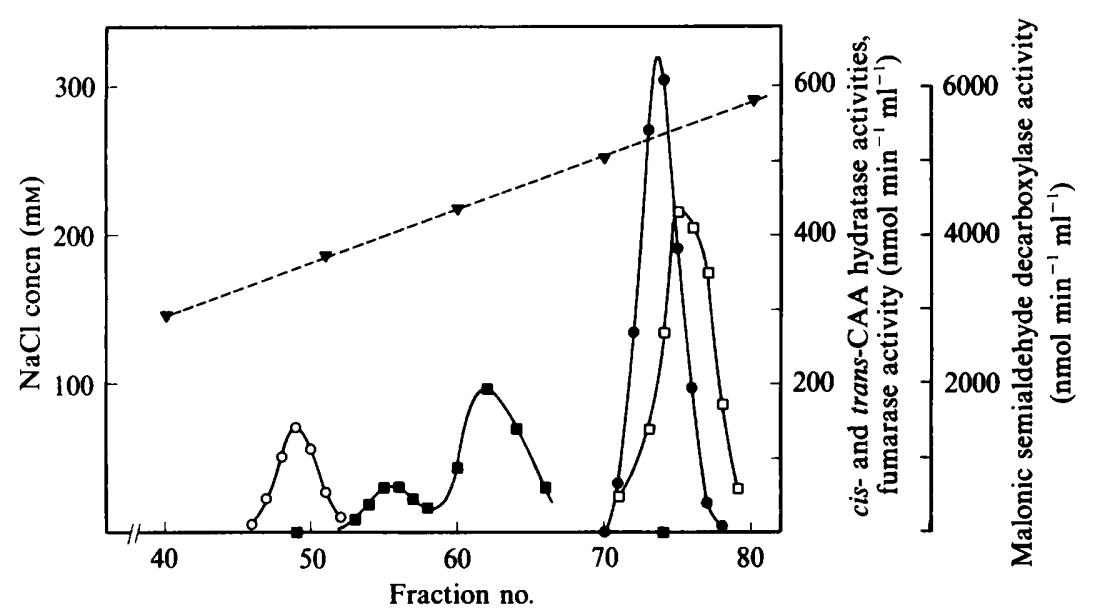

Fig. 2. Separation of cis-CAA hydratase (O), fumarase ( $\square$ ), trans-CAA hydratase $(\bullet)$ and malonic semialdehyde decarboxylase ( $\square$ ) activities with a DEAE-Sepharose CL-6B column $(25 \times 2.5 \mathrm{~cm})$. Elution was with 50 mm-potassium phosphate buffer, $\mathrm{pH} 7 \cdot 0$, with a linear gradient of $100-500 \mathrm{~mm}-\mathrm{NaCl}(\nabla)$ at a flow rate of $50 \mathrm{ml} \mathrm{min}{ }^{-1}$. Fraction vol. was $8.3 \mathrm{ml}$.

determine the $\mathrm{pH}$ optimum, the $K_{\mathrm{m}}$ for CAA and the substrate specificities. The specific activities of the partially purified preparations of the cis-CAA and trans-CAA dechlorinating activities were, respectively, 1300 and $2600 \mathrm{nmol} \mathrm{min}^{-1} \mathrm{mg}$ protein ${ }^{-1}$.

\section{Product identification}

The product of the CAA dechlorinating activity was assumed to be malonic semialdehyde. To confirm this hypothesis 2,4-dinitrophenylhydrazones were prepared after incubating the partially purified trans-CAA dechlorinating activity with its substrate. Van den Tweel $\&$ de Bont (1985) reported that the mass spectra of the malonate semialdehyde and acetaldehyde 2,4-dinitrophenylhydrazones are identical due to the decarboxylation of malonate semialdehyde during 2,4-dinitrophenylhydrazone preparation. The mass spectrum of the 2,4-dinitrophenylhydrazone of the product formed by the trans-CAA dechlorinating activity was indeed identical to that of the 2,4-dinitrophenylhydrazone of authentic acetaldehyde and to the spectrum of the 2,4-dinitrophenylhydrazone of acetaldehyde published by Kanner \& Bartha (1982). Further identification of the product was undertaken using HPLC, as the identification of acetaldehyde only gave indirect evidence for the formation of malonate semialdehyde from CAA.

Analysis of the unsubstituted phenylhydrazones formed during the standard CAA hydratase assay using phenylhydrazine, rather than 2,4-dinitrophenylhydrazine, was possible with reverse-phase HPLC. Both dechlorinating activities gave phenylhydrazones with the same retention time $(4.1 \mathrm{~min})$ upon HPLC analysis and the same UV spectrum. Incubation of cell extracts of 3-butyn-1-ol-grown Pseudomonas BB1 (van den Tweel \& de Bont, 1985) with propynoic acid and phenylhydrazine yields the phenylhydrazone of malonate semialdehyde. This phenylhydrazone was, based on HPLC and UV analysis, identical to the phenylhydrazones that were formed from CAA. The phenylhydrazone of acetaldehyde also had the same UV spectrum (dissolved in ethyl acetate) but was, probably due to the very low solubility in the HPLC eluent, not detectable with HPLC. The phenylhydrazone of pyruvate had a markedly different UV spectrum and also a different retention time ( $2.7 \mathrm{~min})$ upon HPLC analysis.

Based on these results it is concluded that strain CAA2 contained two distinct enzymes that dechlorinate the respective isomers of CAA, both yielding malonate semialdehyde as product. Belser \& Castro (1971) had already demonstrated that whole cells could transform CAA to malonate semialdehyde, but they proposed a difficult-to-envisage 'hydroxylation' of CAA as the dechlorinating step. Although the dechlorinating enzymic activities could perhaps be characterized as dehalogenases (halidohydrolases), characteristics such as the $\mathrm{pH}$ optimum and substrate specificity indicate that these enzymes share more similarity with hydratases like fumarase. Therefore, it is assumed that the CAA hydratases should indeed be classified as hydratases (EC 4.2.1.-), rather than as dehalogenases.

The $\mathrm{pH}$ optimum of cis-CAA hydratase was rather broad and lay between $\mathrm{pH} 7 \cdot 3$ and $8 \cdot 0$, whereas the $\mathrm{pH}$ optimum of trans-CAA hydratase was more pronounced at pH 7.3. The $K_{\mathrm{m}}$ for cis-CAA was $2.5 \mathrm{mM}$ and the $K_{\mathrm{m}}$ for trans-CAA was $0.2 \mathrm{mM}$. In both cases slight substrate inhibition was observed at substrate concentrations 
above $5 \mathrm{~mm}$. The relatively broad $\mathrm{pH}$ optimum observed for cis-CAA hydratase is possibly a reflection of the substrate concentration of $2.5 \mathrm{~mm}$ which was used in the activity assay. A similar observation has been made for fumarase activity where the $\mathrm{pH}$ optimum (pH 6.9) was much less pronounced when the fumarate concentration in the activity assay approached the $K_{\mathrm{m}}$ value (Alberty $e t$ al., 1954). The $\mathrm{pH}$ optima of the two hydratases are therefore very similar to the $\mathrm{pH}$ optimum of fumarase. In contrast, the $\mathrm{pH}$ optima of dehalogenases are much higher. For haloalkane dehalogenases $\mathrm{pH}$ optima of 8.2 and 9.5 have been determined (Keuning et al., 1985; Scholtz et al., 1987) and for 2-haloacid dehalogenases $\mathrm{pH}$ optima of 9.5 are common (Smith et al., 1990).

The substrate specificity of the two hydratases was very high. Several chlorinated compounds were tested as potential substrates for both hydratases. No enzymic liberation of $\mathrm{Cl}^{-}$(detection level $<3 \%$ of the activity measured with the CAA isomer) was, however, detected with 1,3-dichloropropene, 3-chloroallyl alcohol, 2chloroacrylic acid, 1-chloropropene, vinyl chloride, cis1,2-dichloroethene, trans-1,2-dichloroethene or 3-chloropropionic acid.

Special attention was given to vinyl chloride as we are interested in methods to remove this carcinogenic compound from industrial wastes (Hartmans et al., 1985). Hypothetically, hydration of vinyl chloride would result in the formation of either 1-chloroethanol or 2-chloroethanol. 1-Chloroethanol would decompose to acetaldehyde and $\mathrm{HCl}$, but 2-chloroethanol is stable under the assay conditions. By adding 1,2-dichloroethane-grown cells of Xanthobacter autotrophicus GJ10 (Janssen et al., 1985) to the incubation mixture of CAA hydratase with vinyl chloride, any 2-chloroethanol that would be formed would be oxidized and dehalogenated resulting in $\mathrm{Cl}^{-}$formation. However, in the presence of cells of $X$. autotrophicus $\mathrm{GJ} 10$ no $\mathrm{Cl}^{-}$formation was detected, indicating that vinyl chloride is not hydrated by the CAA hydratases of strain CAA2. Apparently, the presence of a carboxyl group adjacent to the chloroethenyl group is a prerequisite for enzymic hydration of the carbon-carbon double bond by the two CAA hydratases of strain CAA2.

Besides chlorinated compounds several non-chlorinated unsaturated carboxylic acids were tested as substrates for the partially purified hydratases. Hydration of acrylic acid, propynoic acid, crotonic acid, trans-2-pentenoic acid, cinnamic acid, methacrylic acid and maleic acid was, however, not observed with either of the two hydratase preparations (detection level lower than $1 \%$ of the activity observed with the appropriate CAA isomer as substrate).

The high substrate specificity of the CAA hydratases also indicates that these enzymes apparently share more similarity with a hydratase like fumarase, which has a relatively high substrate specificity (Teipel et al., 1968), than with the dehalogenases, which generally transform a wide range of substrates (Smith et al., 1990). The observed high substrate specificity gives rise to speculations concerning the physiological function of these enzymes. If CAA is indeed the only substrate transformed, this could indicate that these CAA hydratases have evolved as a result of the large-scale application in agriculture of the nematocide 1,3-dichloropropene. In that case, however, the CAA utilizers would also be expected to grow on chloroallyl alcohol, the product formed upon chemical hydrolysis of 1,3-dichloropropene.

A better understanding of the evolutionary origin of the CAA hydratases will, however, require characterization of the nucleotide sequences of the corresponding genes. In this respect the recent data showing extensive sequence homology between fumarase and L-aspartate ammonia-lyase (Takagi et al., 1986) is very interesting. Possibly the CAA hydratases share a common evolutionary origin with these enzymes.

\section{CAA degradation pathway}

Having established that the product of CAA dechlorination was malonic semialdehyde, the degradative pathway of this not-very-common metabolic intermediate was studied. Two enzymic activities oxidizing malonic semialdehyde have been described previously. A NAD ${ }^{+}$-dependent dehydrogenase (EC 1.2.1.15) which oxidizes malonic semialdehyde to malonate (Nakamura \& Bernheim, 1961) and a NAD ${ }^{+}$and CoAdependent malonate semialdehyde oxidative decarboxylase (EC 1.2.1.18) forming acetyl-CoA (Yamada \& Jakoby, 1960). Interestingly, cis-CAA-dependent formation of $\mathrm{CO}_{2}$ was detected in dialysed extracts without adding $\mathrm{NAD}^{+}$or $\mathrm{CoA}$. Incubation of trans-CAA with the partially purified preparation of trans-CAA hydratase also resulted in $\mathrm{CO}_{2}$ formation. No $\mathrm{CO}_{2}$ formation was observed when cis-CAA was incubated with the partially purified cis-CAA hydratase.

This indicated that the partially purified trans-CAA hydratase preparation contained a cofactor-independent malonate semialdehyde decarboxylase, presumably yielding acetaldehyde and $\mathrm{CO}_{2}$, which was not present in the partially purified cis-CAA hydratase. Subsequent experiments with the partially purified trans-CAA hydratase did indeed reveal simultaneous formation of acetaldehyde and $\mathrm{CO}_{2}$ from trans-CAA. Combining of the trans-CAA and cis-CAA hydratase preparations also resulted in acetaldehyde and $\mathrm{CO}_{2}$ formation from cis-CAA. When phenylhydrazine was added to the 
Table 1. Enzyme activities in strain CAAI

Activities are expressed in $\mathrm{nmol} \mathrm{min}^{-1}$ (mg protein) ${ }^{-1}$.

\begin{tabular}{lrcr}
\hline \hline & \multicolumn{3}{c}{ Growth substrate } \\
\cline { 2 - 4 } \multicolumn{1}{c}{ Enzyme } & cis-CAA & Malonate & Succinate \\
\hline cis-CAA dehalogenase & 240 & $<5$ & $<5$ \\
MSA decarboxylase & 530 & 40 & 30 \\
Malonate decarboxylase & $<20$ & 470 & $<20$ \\
Acetaldehyde dehydrogenase & 40 & 35 & 35 \\
Isocitrate lyase & 825 & 695 & 5 \\
Isocitrate dehydrogenase & 585 & 680 & 550 \\
\hline \hline
\end{tabular}

Table 2. Enzyme activities in strain $C A A 2$

Activities are expressed in $\mathrm{nmol} \mathrm{min}^{-1}(\mathrm{mg} \text { protein })^{-1}$.

\begin{tabular}{lrcc}
\hline & \multicolumn{3}{c}{ Growth substrate } \\
\cline { 2 - 4 } \multicolumn{1}{c}{ Enzyme } & cis-CAA & Ethanol & Succinate \\
\hline cis-CAA dehalogenase & 450 & $<10$ & $<10$ \\
trans-CAA dehalogenase & 1200 & $<10$ & 12 \\
MSA decarboxylase & 1160 & 55 & 60 \\
Acetaldehyde dehydrogenase & 25 & 200 & 5 \\
Isocitrate lyase & 1020 & 1010 & 15 \\
Isocitrate dehydrogenase & 560 & 645 & 855 \\
\hline \hline
\end{tabular}

incubation mixture, acetaldehyde and $\mathrm{CO}_{2}$ was no longer observed, but the $\mathrm{Cl}^{-}$formation rate was unaffected.

As malonate semialdehyde was not available from a commercial source the partially purified cis-CAA hydratase preparation, devoid of malonate semialdehyde decarboxylase, was used to produce malonate semialdehyde from cis-CAA in situ to assay malonate semialdehyde decarboxylase activity. With this assay we were able to locate the malonate semialdehyde decarboxylase activity peak in the fractions from the DEAE-Sepharose column. As anticipated, malonate semialdehyde decarboxylase activity more or less coincided with transCAA hydratase activity (Fig. 2).

With the observed enzyme activities a degradative pathway for cis-and trans-CAA in cis-CAA-grown strain CAA2 can be envisaged which proceeds via malonate semialdehyde to acetaldehyde. Subsequently, enzyme activities in crude extracts of cis-CAA-grown cells of both strains and in extracts of cells grown with control substrates were compared. As can be seen in Tables 1 and 2, CAA hydratase and malonate semialdehyde decarboxylase activities were present only after growth with cis-CAA. NAD ${ }^{+}$-dependent acetaldehyde dehydrogenase activities in cis-CAA-grown cells of both strains were rather low. No phenazine methosulphate (PMS)dependent acetaldehyde dehydrogenase activity could be detected in extracts of ethanol-grown cells of strain CAA2. In spite of the observed low acetaldehyde

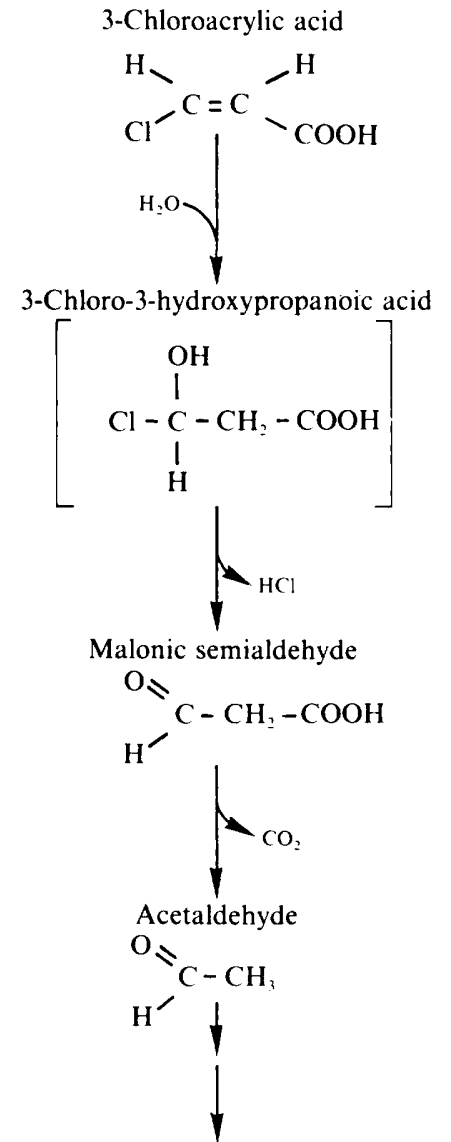

Fig. 3. Proposed pathway for cis-CAA degradation in Pseudomonas cepacia strain CAA1 and the coryneform strain CAA2.

dehydrogenase activities we propose for both strains the cis-CAA degradation pathway summarized in Fig. 3 . Induction of isocitrate lyase activity during growth with cis-CAA is also in agreement with the above pathway.

The presence of malonate decarboxylase activity in cell extracts of malonate-grown strain CAAl, and the absence of this activity in cis-CAA-grown cells, is a further confirmation that, in this isolate, malonate is not an intermediate of cis-CAA metabolism.

Having established the pathway for cis-CAA degradation an explanation for the inhibition of strain CAA2 by the growth substrate trans-CAA was still required. Initial trans-CAA concentrations higher than 2-4 mM gave inconsistent growth and often resulted in a transient accumulation of acetaldehyde. This accumulation of the toxic aldehyde possibly explained the poor growth of strain CAA2 with trans-CAA. No acetaldehyde formation was observed with cis-CAA as carbon source at similar concentrations, probably because cis-CAA hydratase activity is lower.

We would like to thank Alex van Neerven for photography and Dr D. B. Janssen for providing Xanthobacter autotrophicus GJ10. 


\section{References}

Alberty, R. A., Massey, V., Frieden, C. \& Fuhlbrigge, A. R. (1954). Studies of the enzyme fumarase. III. The dependence of kinetic constants at $25^{\circ}$ upon the concentration and $\mathrm{pH}$ of phosphate buffers. Journal of the American Chemical Society 76, 2485-2493.

BAGLEY, D. M. \& GosseTt, J. M. (1990). Tetrachloroethene transformation to trichloroethene and cis-1,2-dichloroethene by sulfatereducing enrichment cultures. Applied and Environmental Microbiology 56, 2511-2516.

Becker, B., Lechevalier, M. P., Gordon, R. E. \& Lechevalier, H. A. (1964). Rapid differentiation between Nocardia and Streptomyces by paper chromatography of whole-cell hydrolysates. Applied Microbiology 12, 421-423.

Belser, N. O. \& CASTRo, C. E. (1971). Biodehalogenation - the metabolism of the nematocides cis- and trans-3-chloroallyl alcohol by a bacterium isolated from soil. Journal of Agricultural and Food Chemistry 19, 23-26.

BergmanN, J. G. \& SANIK, J. (1957). Determination of trace amounts of chlorine in naphtha. Analytical Chemistry 29, 241-243.

vaN DiJK, H. (1980). Dissipation rates in soil of 1,2-dichloropropane and 1,3- and 2,3-dichloropropenes. Pesticide Science 11, 625-632.

Fathepure, B. Z. \& Boyd, S. A. (1988). Dependence of tetrachloroethylene dechlorination on methanogenic substrate consumption by Methanosarcina sp. strain DCM. Applied and Environmental Microbiology 54, 2976-2980.

Freedman, D. L. \& GossetT, J. M. (1989). Biological reductive dechlorination of tetrachloroethylene and trichloroethylene to ethylene under methanogenic conditions. Applied and Environmental Microbiology 55, 2144-2151.

Hartmans, S., De Bont, J. A. M., Tramper, J. \& Luyben, K. Ch. A. M. (1985). Bacterial degradation of vinyl chloride. Biotechnology Letters 7, 383-388.

Hartmans, S. \& DE Bont, J. A. M. (1986). Acetol monooxygenase from Mycobacterium Pyl cleaves acetol into acetate and formaldehyde. FEMS Microbiology Letters 36, 155-158.

Hartmans, S., Jansen, M. W. \& DE Bont, J. A. M. (1988) 3-Chloroacrylic acid metabolism in bacteria. In Microbial Physiology and the Manufacturing Industry, p. 205. Edited by C. Ratledge, A. Szentirmai, G. Barabás \& F. Kevei. Budapest: OMIKK.

Hartmans, S., De Bont, J. A. M. \& Harder, W. (1989). Microbial metabolism of short-chain unsaturated hydrocarbons. FEMS Microbiology Reviews 63, 235-264.

JansSen, D. B., Scheper, A., Dijkhuizen, L. \& Witholt, B. (1985). Degradation of halogenated aliphatic compounds by Xanthobacter autotrophicus GJ10. Applied and Environmental Microbiology 49, 673-677.
JONES, D. \& KEDDIE, R. M. (1986). Genus Brevibacterium. In Bergey's Manual of Systematic Bacteriology, vol. 2, pp. 1301-1313. Edited by P. H. A. Sneath, N. S. Mair, M. E. Sharpe \& J. G. Holt. Baltimore: Williams \& Wilkins.

KANNER, D. \& BARTHA, R. (1982). Metabolism of acetylene by Nocardia rhodochrous. Journal of Bacteriology 150, 989-992.

Keuning, S., Janssen, D. B. \& Witholt, B. (1985). Purification and characterization of hydrolytic dehalogenase from Xanthobacter autotrophicus GJ10. Journal of Bacteriology 163, 635-639.

Kohler-Staub, D. \& Leisinger, Th. (1985). Dichloromethane dehalogenase of Hyphomicrobium sp. strain DM2. Journal of Bacteriology 162, 676-681.

Marletta, M. A., Cheung, Y. F. \& Walsh, C. (1982). Stereochemical studies on the hydration of monofluorofumarate and 2,3-difluorofumarate by fumarase. Biochemistry 21, 2637-2644.

Motosugi, K., Esaki, N. \& Soda, K. (1982). Purification and properties of a new enzyme, DL-2-haloacid dehalogenase, from Pseudomonas sp. Journal of Bacteriology 150, 522-527.

NaKamura, K. \& Bernheim, F. (1961). Studies on malonic semialdehyde dehydrogenase from Pseudomonas aeruginosa. Biochimica et Biophysica Acta 50, 147-152.

Scholtz, R., Leisinger, Th., Suter, F. \& CoOK, A. M. (1987). Characterization of 1-chlorohexane halidohydrolase, a dehalogenase of wide substrate range from an Arthrobacter sp. Journal of Bacteriology 169, 5016-5021.

Smith, J. M., Harrison, K. \& Colby, J. (1990). Purification and characterization of D-2-haloacid dehalogenase from Pseudomonas putida strain AJ1/23. Journal of General Microbiology 136, 881-886.

TAKagi, J. S., Toxushige, M., Shimura, Y. \& Kanehisa, M. (1986). L-Aspartate ammonia-lyase and fumarate hydratase share extensive sequence homology. Biochemical and Biophysical Research Communications 138, 568-572.

Teipel, J. W., Hass, G. M. \& Hill, R. L. (1968). The substrate specificity of fumarase. Journal of Biological Chemistry 243, 5684-5694.

VAN DEN TWEel, W. J. J. \& DE BoNT, J. A. M. (1985). Metabolism of 3-butyn-1-ol by Pseudomonas BB1. Journal of General Microbiology 131, 3155-3162.

Wackett, L. P., Brusseau, G. A., Householder, S. R. \& Hanson, R. S. (1989). Survey of microbial oxygenases: trichloroethylene degradation by propane-oxidizing bacteria. Applied and Environmental Microbiology 55, 2960-2964.

YAMADA, E. W. \& JAKOBY, W. B. (1960). Aldehyde oxidation. V. Direct conversion of malonic semialdehyde to acetyl-coenzyme A. Journal of Biological Chemistry 235, 589-594.

Yokota, T., Fuse, H., OMORI, T. \& Minoda, Y. (1986). Microbial dehalogenation of haloalkanes mediated by oxygenase or halidohydrolase. Agricultural and Biological Chemistry 50, 453-460. 